\title{
ENGLISH NARROWBOATS: FROM INDUSTRIAL REVOLUTION TO THE URBAN HOUSING PROBLEM
}

(DOI No: 10.3940/ijme.2021.a1.684)

J Pérez-Martínez, Royal Institution of Naval Architects, UK and Universidad Politécnica de Madrid, Spain, R Pérez Fernández, Universidad Politécnica de Madrid, Spain

KEY DATES: Submitted: 22/11/2020, Final acceptance: 14/12/2020, Published: 25/03/2021

\section{SUMMARY}

The housing scene in major cities is driving people into unconventional real estate options, and London is no exception. As rental and purchase prices have risen, some individuals have turned to houseboats for an affordable option. The waterbodies, that were a main driver of the development of the city, have experienced the consequences of that growth and the degradation that followed. In this paper, the impact of the increase in waterway short-stay and permanent moorings is explored. Several events in the rich history of English canals are discussed, as well as their relevance to the current situation. The needs and main limitations are also considered, as these are putting pressure on the communities, agencies and authorities involved. The constraints, especially spatial, of this type of housing present an interesting challenge for boat designers who need to adapt to the next generation of boaters' requirements. Additionally, improvement of the facilities and infrastructure is important to protect the rights of all waterway users and the wider public.

\section{NOMENCLATURE}

BW British Waterways

CRT Canal and River Trust

MDF Medium Density Fibreboard

ONS Office for National Statistics

\section{INTRODUCTION}

Almost uninterruptedly, house prices in England have been rising steadily for the last two decades, as it has been illustrated by Figure 1. Every year record highs have been registered, and not even the recent pandemic has been able to overturn that trend. London real state has been above the average in England, but from 2012 those prices have soared significantly. This situation has led to a higher number of residents to turn to houseboats for a more affordable housing option.

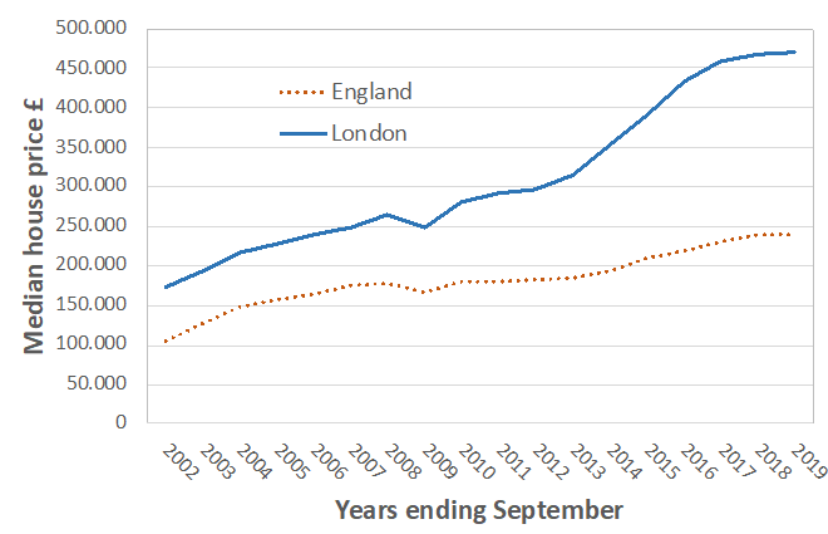

Figure 1: Median house price England and London year ending September 2002 to year ending September 2019. (ONS, 2020)
The Office for National Statistics (ONS) has provided data that suggest an increase in the affordability ratio. Those refer to the ratio of the median price paid for residential property to the median workplace-based gross annual fulltime earnings (ONS, 2020). The affordability of fifteen London boroughs north of the Thames with waterways are shown in Figure 2.

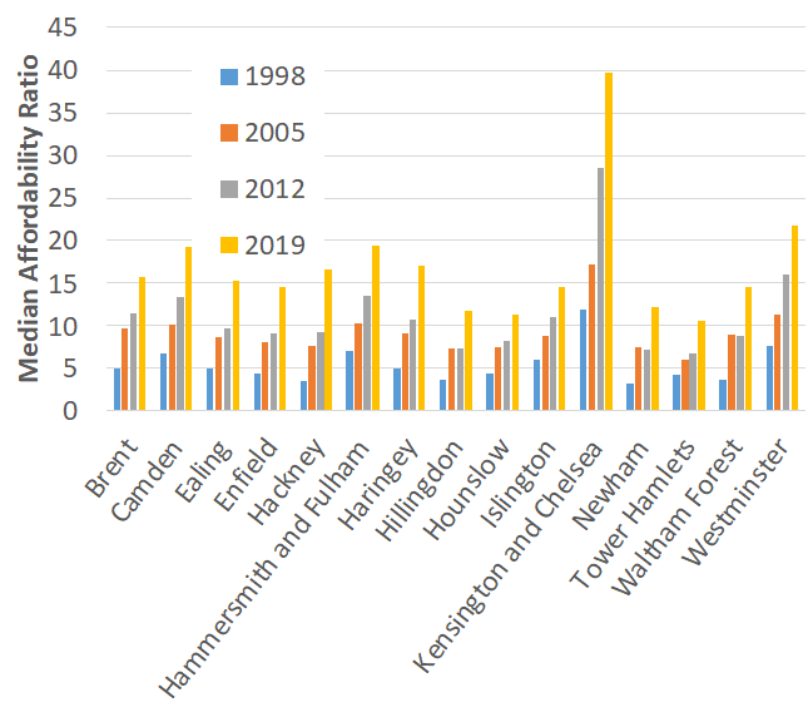

Figure 2: Median Affordability Ratio of 1998-2019 from the 15 Boroughs that have waterways under the CRT control. (ONS 2020)

In order to better illustrate those London boroughs, Figure 3 has been included. Please note that although South London has waterways including rivers, their relevance is significantly lower due to urbanization developments. Those resulted in the closure of two canals, the Grand Surrey Canal and the Croydon Canal, the latter has the distinction of being the first canal to be abandoned by an Act of Parliament in 1836. 


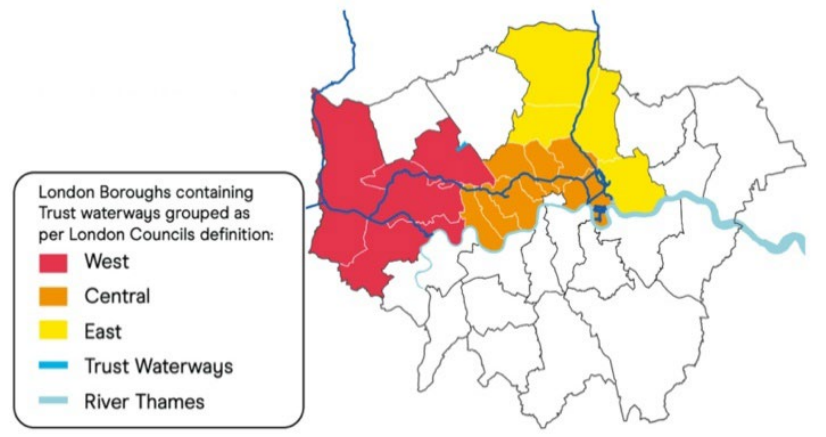

Figure 3: Boroughs north of the Thames under CRT control. Source: CRT

After addressing the London's housing price rise the first thing that we must state what is a houseboat. The wide range of options include the classic narrowboats, transformed fishing vessels, yachts and the widely used barges among others. These floating houses can look more like houses than boats and vice versa, some self-propelled while others are towable or for permanent mooring. Under the waterline the buoyancy can be provided by means of a monohull, multihull, logs or floating barrels and boxes. Most boats in British waterways fall in the classification of narrowboats, widebeams, Dutch Barges, cruisers and trailer boats. The prices can vary significantly, but an estimate of the average cost of a narrowboat in London made by Towergate insurance would be $£ 57,000$. With prices that range between $£ 15,000$ and $£ 150,000$ those are significantly lower than the ones discussed for the conventional housing.

The Blue Ribbon Network, is the London's strategic water network. It comprises the London's rivers, canals, docks, reservoirs and lakes. The Network's map is featured in Figure 4. This waterway network is currently managed by The Environment Agency, Port of London Authority and Canal and River Trust (CRT).

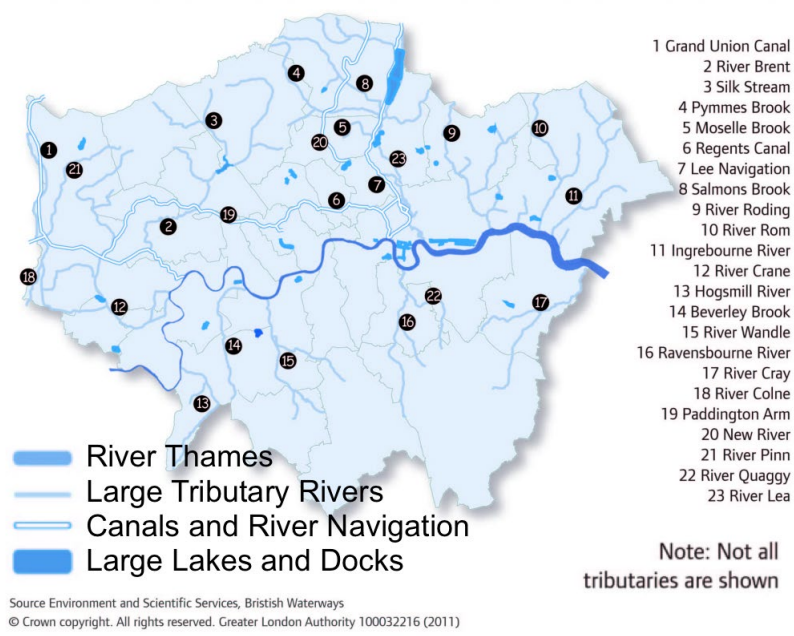

Figure 4: London's Blue Ribbon Network. Source: www.london.gov.uk
This vast man-made network was the result of more than two centuries of work, and it requires a thorough analysis of the history behind it.

\section{INDUSTRIAL REVOLUTION}

The First Industrial Revolution arrived with the introduction of machines into production by the end of the $18^{\text {th }}$ century. This involved going from manual production to the use of steam-powered engines and water as a source of power. The discovery of new methods in the use of coal made iron and steel cheaper and, increased the use of those materials in construction. This also resulted in the reduction of the use of wood as fuel, but it required new logistics for the transport of this mineral that could compete in price to ensure its demand. This was evident with the flourishing use of canal transport in countries such as the United Kingdom (Wrigley, 1962).

The first pure canal in the UK was completed in 1741, which was the Newry Canal. Although there were records of Coal mining in 1654 in east Tyrone, it wasn't until the increase output from Francis Seymour's mining operation that there was a need to transport large quantities of coal in a more efficient way. It is considered that a wheeled vehicle pulled by a horse would carry about a ton, and when using a barge that same horse could pull seventy ton. Although the first successful steamboat, the Clermont, was built by Robert Fulton in 1807 the horse-drawn boats will remain an economical means of transportation well into the early $20^{\text {th }}$ Century.

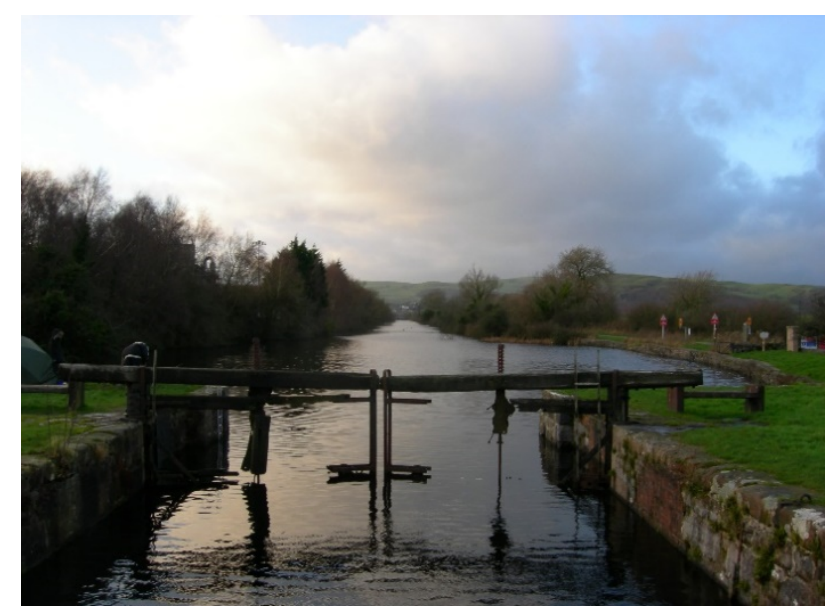

Figure 5: The Ulverston Canal accommodated in the past thousands of vessels. Photo taken by R. Perez in 2009

Other countries in Europe were also aware of the advantageous use of inland waterways for transport. France with the Briare and Languedoc canals, the Willebroek Canal in current Belgium or the Stecknitz Canal in Germany among others. In Spain, an ambitious project of four canals called the Canal de Castilla, began construction in 1753 under the proposal of the Marqués de la Ensenada, and whose project was developed by Antonio de Ulloa. This pharaonic work was interrupted on several 
occasions and began operation 100 years later, in 1849 . Despite a total length of $207 \mathrm{~km}$, its use became obsolete with the introduction and development of the railway, which bears some resemblance with the evolution that will be discussed in the following chapter.

As a curiosity, mention that the Ulverston Canal (Cumbria), in Figure 5, with 1.25 miles long, is considered the straightest canal in Britain. The Wardle Canal (Cheshire), 154 feet long, the shortest. And the Manchester Ship Canal the deepest with 28 feet.

Just 50 years after Newry Canal, the UK was overwhelmed by a craze called the canal mania, where between 1791 and 1794 an astonishing number of 42 canals were built. Which represent a third of all investment up to 1830 (Bagwell, 1988). Shortly after in 1812 the Regents Canal first opened for operation and was part of a waterway system that communicate the world to England's industrial heartlands.

\section{DECLINE}

The decline of canal transportation can be due to many factors, but it is largely understood that it was mainly due to the railway monopoly that was gaining predominance by 1845 . The fragmented organization of the waterway system, with a multitude of authorities, was unable to prevent the absorption of key sections of the canal network during the period of 1845 to 1872 . Although railways favoured high-value traffic, they rapidly began transporting low-margin freight such as coal (Gourvish, 1980). Nevertheless, in some communities the inland water transport of passengers and lighter cargo was preferred when faster packet boats could be used in canals where features such as locks were in low numbers. This was true in lower gradient canals found in Scotland, which were able to keep in operation but had their fares greatly affected.

The first modern Railway System in the UK is considered to be the Liverpool and Manchester Railway, which opened in 1830 . That railway showed great returns, which encouraged high investments and created a railway mania that by 1850 had those profits largely diminish. Partly due to inefficiencies in the operation and cost management as they experienced weak competition. The railway industry persistently failed to produce the required returns, and in some cases suffered from low profitability (Mitchell et al., 2009).

Despite the introduction of the Railway and Canal Traffic Act 1854, the growing monopoly of the Railways made the inland waterways less competitive as it mainly focused on the obligation to carry. Subsequent Traffic Acts focused on rates and facilities, and the intervention from parliament did not impede the railways to take control of more than a third of the mileage of canals in the UK by the end of the $19^{\text {th }}$ century. Some would transform them into railways; other closed or used it as means to access the district of a competitor.

Thanks to different town councils and trusts, it was possible to maintain many of the canals, making conceivable the later revitalization.

\section{REVITALISATION}

It can be considered that a new chapter of the canals was opened when in 1947, after World War II, the canal and railway systems were nationalized by the Labour Government. That gave birth to the British Railways (BR) which operated as a state-owned company from 19481997. However, a different case happened with British Waterways (BW) that was established under the Transport Act 1962, with the purpose to operate and maintain the waterways, docks and harbours in Great Britain. This Statutory Corporation gradually restored and reopened the waterways, which at the time were in dire need of renovation, and their use was primarily for leisure. At the time, the BW was operating and maintaining a network of $2,700 \mathrm{~km}$ of canals and $500 \mathrm{~km}$ of navigable rivers, 1,657 locks and 2,664 listed buildings. Which benefited from the various restoration projects led by volunteer groups, societies and trusts. (Rhodes et al., 2014)

In 2012, coincidentally with the steep rise on house prices in London, the government transferred the assets and statutory functions to a charitable trust already mentioned called the CRT, and which currently operates and maintains the canals and waterways in England and Wales. That same year the Waterways Infrastructure Trust Settlement was signed to protect the public use of those waterways, to keep free access terms of access to the towpaths and keep them unsalable. The government placed a long term funding scheme, which is providing different grants over a period of 15 years until it is reviewed in 2027.

\section{FROM LEISURE TO HOUSING}

Living on the boats was not a new idea but it was largely done in the $19^{\text {th }}$ Century. When approximately 25,000 barges on inland waterways resulted in a floating population of no less than 50,000 (Bagwell, 1988).

In the earlier years normally, there were only two people permanently in those boats, the boatman and an aid. Larger boats, $40-50$ ton, were manned by a captain, two mates and marine. That would be the configuration of the ill-fated Tilbury, which blew up while navigating the Regents Canal in October 1874 and accelerated the approval of the Explosives Act in 1875. The marine would normally sleep ashore during trips to take care of the horses. They would share the duties of steering, the leading of the horses, and the working of the lock paddles and gates. When competition with the railways started, that situation worsened, and lower wages made land based 
housing unaffordable for the boaters and their families. They resorted to move their families into the boats, which was challenging due space and sanitary conditions. To fight against this situation the government introduced the Canal Boats Act of 1877, which was a failure in the words of the medical officer in the British Medical Journal (Browning, 1879).

Although larger boat owners did comply with the regulations, smaller boats were reluctant to follow the Act, mainly concerning children on board. Uncertificated and unsanitary boats could continue to operate due to the lack of enforcement. There was an attempt to palliate those issues with an Amendment in 1884. There are reports that suggest that 1895 there were 4,000 children living on boats, by 1938 that number had fallen to 600 (Bagwell, 1988).

As the Liverpool Journal published in September 1877, wider barges had cabins of about $1.68 \mathrm{~m}$ ( $5 \mathrm{ft} 6 \mathrm{in}$ ) high and an area of $2.74 \mathrm{~m}(9 \mathrm{ft})$ by $2.74 \mathrm{~m}$. Leaving a sleeping berth of $0.9 \mathrm{~m}$ wide. That was not the case for navigation in canals

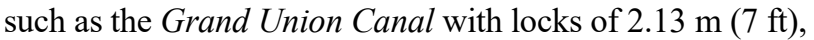
which subsequently required narrower beams. In those cabins a bed, seating, table and back cabin stove had to be fitted. A smaller space was also available in the forecastle.

It is believed that the popularization of family living in the narrowboats brought the aesthetic that we know today. Externally the introduction of bright colours with mainly the motif of roses and castles and other ornaments were added, and internally the space economy and decorations to give a simple but comfortable living. All the domestic inclusions had to be done avoiding affect the main purpose of the boat, which was carrying the goods, so it had to be constrained to the available space.

After the nationalization of the BW and subsequent post-war revitalization the canals remained primarily commercial with also some leisure boats. By the end of the $20^{\text {th }}$ century the commercial use had disappeared, but those boats were converted into leisure boats although other were abandoned. As the house prices have soared during the last decade, converted and new build boats have almost doubled their number in London as shown in Figure 6.

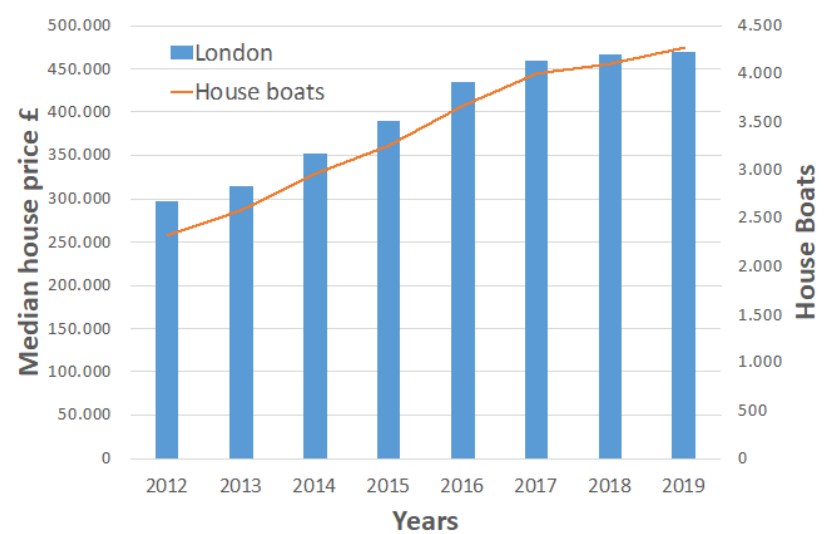

Figure 6: London's median house price compared with houseboat growth
The living conditions can vary greatly between the mooring, vessel size, condition and location, which undoubtedly affects the cost of living.

\section{$5.1 \quad$ LICENSING SYSTEM}

The CRT issues Mooring permits that brought $£ 8.1 \mathrm{~m}$ during the $2019 / 2020$ period. That income increased $5.2 \%$ due to general inflationary price rises and improved occupancy levels (Canal \& River Trust, 2020). Those permits are charged per metre and month, and the area in which they are located plays an important role in the final fee.

The number of licensed boats on London waterways was 4,274 in 2019, which is a great increase considering that in 2012 the number was 2,326 . That growth has resulted in an increasingly competitive scenario especially in high demand areas as an Auction System was introduced. The alternative to the long-term home mooring is to have the Long Term Licence that for the period 2020/21 the CRT charged between $£ 55.05$ and $£ 1237.65$ for a 12 -month period. That is significantly lower than the reported $£ 20,000$ a year that some moorings have reached via auction.

\subsection{DIMENSIONS}

The dimensions of those boats can vary significantly, but if we only consider narrowboats, the beam is a dimension that is kept constant. The papers referred to the Grand Union Canal because of the width constrain due to the locks, but there are other such as draught and headroom. The latter is relevant due to the several bridges along the canal.

Table 1: Grand Union Canal waterway limitations Source: (Canal \& River Trust, 2020)

\begin{tabular}{|c|c|c|c|c|}
\hline Waterway & Length & Width & Draught & Headroom \\
\hline $\begin{array}{l}\text { River Thames } \\
\text { into Limehouse } \\
\text { Basin only }\end{array}$ & 28 & 7.5 & - & - \\
\hline Regents Canal & 22.36 & 4.22 & 1.28 & 2.64 \\
\hline $\begin{array}{l}\text { Hertford Union } \\
\text { Canal }\end{array}$ & 26 & 4.45 & 1.3 & 2.33 \\
\hline $\begin{array}{l}\text { River Thames } \\
\text { into Brentford } \\
\text { Basin only }\end{array}$ & 22.87 & 5.02 & - & - \\
\hline $\begin{array}{l}\text { Lock } 82 \\
\text { Rickmansworth } \\
\text { to Berkhamsted }\end{array}$ & 21.95 & 4.27 & 1.23 & 2.28 \\
\hline Aylesbury Arm & 22.57 & 2.13 & 1.29 & 2.28 \\
\hline $\begin{array}{l}\text { Northampton } \\
\text { Arm }\end{array}$ & 22.57 & 2.13 & 1.23 & 2.18 \\
\hline $\begin{array}{l}\text { Bulls Bridge to } \\
\text { Little Venice }\end{array}$ & - & 4.3 & - & 2.08 \\
\hline $\begin{array}{l}\text { Brentford to } \\
\text { Bulls Bridge }\end{array}$ & 22.2 & 4.26 & 1.48 & 2.88 \\
\hline $\begin{array}{l}\text { Bulls Bridge to } \\
\text { Stockers Lock }\end{array}$ & 21.95 & 4.26 & 1.03 & 2.34 \\
\hline Slough Arm & - & 4.92 & - & 2.33 \\
\hline Wendover Arm & 21.95 & 2.13 & - & - \\
\hline
\end{tabular}


The table above gives some information of the limitations of the Grand Union Canal, whose main line includes 158 locks along 158 miles.
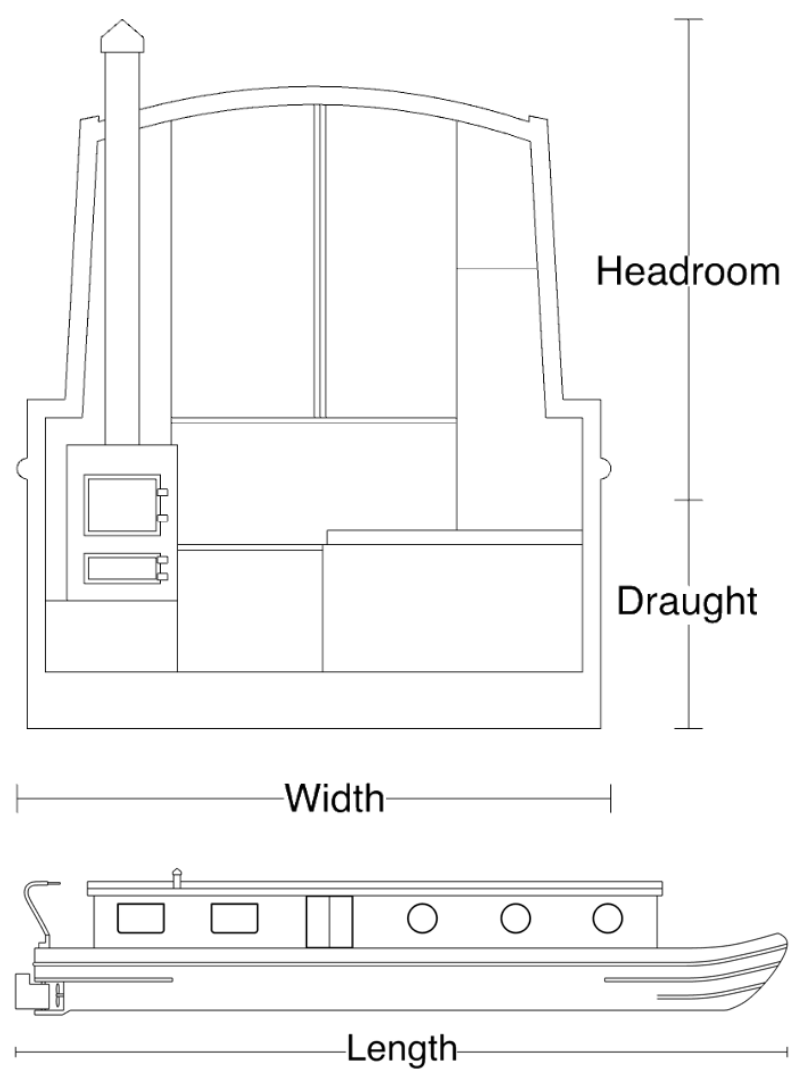

Figure 7: Example of narrowboat section and side view. Showing definitions of principal dimensions. Drawings by J. Pérez-Martínez.

\subsection{MATERIALS}

\subsubsection{Hull and superstructure}

Although traditional narrowboats were built from wood, currently most ships have both hull and superstructure made from steel. Nevertheless, there are still different combinations of wood, aluminium, steel and fibreglass boats available.

By the end First World War, wartime shortages of wood and steel will have the concrete boat idea reappearing. Those boats could be traced back to Joseph Louis Lambot first concrete boat in 1848 , but their production was abruptly interrupted due to low payload.

\subsubsection{Interior}

The interior of those ships can also vary significantly depending on if they are new builds or conversions. Due to the do-it-yourself attitude of the inland boating community, the budget constraints can produce really innovative designs.
Steel will be generally found in bulkheads to separate tanks and engine bays. But the engine compartment can be separated by lighter materials such as wood or fibreglass. On the other hand, Medium Density Fibreboard (MDF) is usually not recommended due to the moisture resistance and mechanical properties.

\section{$5.4 \quad$ APPPLIANCES}

As previously stated, the huge range of boats and origin also create a great number of different capabilities. Bigger boats are able to accommodate numerous appliances including cookers, showers, dishwashers, fridges, washing machines and event toilets. Space limitations are a common challenge to all boats, but specially narrowboats. The aforementioned appliances became more common in smaller boats as they moved from recreational towards residential use; traditionally they were equipped with little more than a stove.

Marinas offer on-site showers, toilets, laundry facilities, pumps, electricity, water, and even Wi-Fi and car parking. For boaters that do not have those permanent mooring facilities or have cruisers licences they will rely on the publicly available waterway facilities on the waterway. That will be particularly relevant when using pump-outs or cassette toilets.

Inland navigation has many limitations, especially with noise, waste disposal, toilets and pollution. As this paper discussed urban area boating, the public concern with noise and pollution is of utmost importance. As cruising is an off-the-grid alternative, the heat and energy requirements may be satisfied using electricity, diesel, gas or wood logs. Heat generation has traditionally been given by stoves, whose only output is the smoke and smell we are used to experiencing in the canals. However, electricity requirements are normally met using generators that produce noise and fumes that are usually a nuisance to the neighbouring population. Sanitary conditions can also deteriorate in areas with limited waste disposal and toilet facilities. There have been projects such as the Bins by Boat trial for waste collection directly from boats as an alternative to limited towpath facilities.

\subsection{TYPES OF MOORING}

The types of mooring are normally divided depending on the time they will stay including Long-term, Short-stay, Waterside and Winter Mooring. Permanent moorings or home moorings, are normally either private companies, boat clubs or the CRT that provide different levels of services. These have prices that are according to the popularity of the area and in the case of the CRT auctions, the periods are 1 or 3 years and for an available length, which is independent to the boat's length. The Short-stay mooring on the other hand considerably reduced stays but can range from 4 hours (called shop and drop) to 48 hours, to even 7 day or 14 days. These last types of moorings are free, but require the licences discussed previously. 
It is important to highlight that in 2019 the number of boats with a permanent mooring in London was 2.066, that compared with the 1.688 in 2012 is a fairly flat increase compared with the boats without a permanent mooring. Those last ones changed from $27 \%$ in 2012 to $52 \%$ of the entire fleet, which illustrates a predominant choice of short-term mooring as the long-term mooring is not meeting the demand.

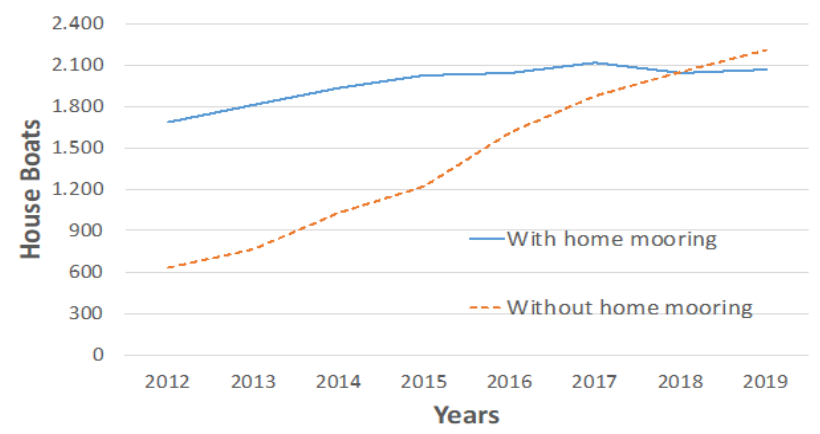

Figure 8: Home mooring and temporary mooring boats in London between 2012-2019

Due to the over-occupancy, long-term mooring percentage has decreased dramatically while prices have risen substantially. The need for more long term mooring facilities has become evident, and not only the CRT is working towards a solution. Other private companies, including wharfs and marinas, build and manage longterm residential boat moorings.

On the other hand, that increase on population has resulted in higher tension between the communities adjacent to the waterways, as the lifestyle of those living in affluent boroughs may collide with the ones from the boating community.

\subsection{ALTERNATIVE FLOATING ASSETS}

It is not uncommon to see different boats and floating structures in the current London canal scene. Due to the constricted dimensions of the classic narrowboats. Those can be sailboats, powerboats, floating houseboats, and even lifeboats. Figure 9 shows a 9.5 -meter 49 persons Phoenix lifeboat conversion seen in the Grand Union Canal Paddington Arm on March 2019 by the author.

As the narrowboat offer reduced space, it is common to see bigger boats on marinas such as Canary Wharf or Limehouse. The arrival of $62 \mathrm{ft}$ foot Dutch Barges, widebeam boats and yachts offer a still comparatively affordable and more comfortable alternative in the areas where they are moored.

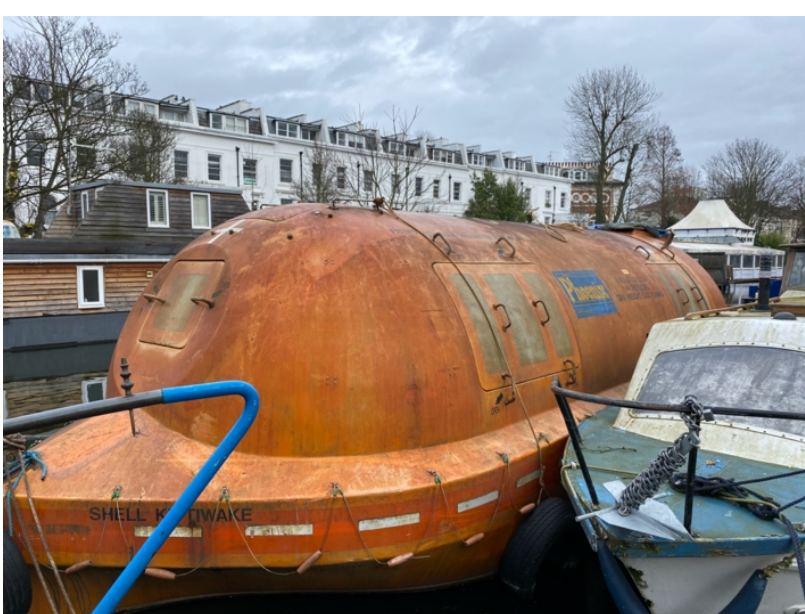

Figure 9: 49 persons lifeboat Grand Union Canal, Paddington Arm. Photo taken by J. Pérez-Martínez

\section{OTHER WATER BASED URBAN DEVELOPMENTS - THE NETHERLANDS}

It is no wonder that the Netherlands is considered a pioneer when it comes to floating houses. Around a quarter of the country lies below sea level. For the Dutch, water has long been an important element of urban planning. Amsterdam, that currently has about 2500 houseboats registered, is a major European city known worldwide for the many houseboats that create additional living space in the canals.

Amsterdam's canal belt, that can be traced back to the $17^{\text {th }}$ century, has a length of 60 miles and was the result of the continuous expansion of the city. Originally, they served the purpose of defensive canals, that were later converted into residential areas. As with London, living in boats and barges began a common practice in the $19^{\text {th }}$ century.

Amsterdam has a permit system, called ligplaats, which entitles the boat to be moored in a specific address. That system has also resulted in gentrification due to the lack of new permits being released, which is common in large cities.

There is a new neighbourhood close to Amsterdam, IJburg, which was created on artificially raised sand islands. In the first construction phase, a total of 18,000 apartments with living space for 45,000 people were created. Lacking a firm subsoil, the neighbourhood functions primarily with bridges and jetties, which provide access to the residences. Gardens are not allowed but living close to the water makes up for it. A lock ensures that the inland sea on which the houses float is separated from the IJMeer (a bordering lake in Netherlands). This prevents the apartments from drifting out to sea. The project was completed almost ten years ago, including both social housing and condos. 
The Dutch architectural company Waterstudio. NL has built this year 2020 a solar-powered electric waterfront villa with retractable stilts that allow it to be raised up completely out of the water to convert in an off-grid home. Another example is the Arkup 75, a floating house, designed with a hybrid foundation that allows it to float when moving, be semi-supported when alongside a dock or fully raised up from the water (Waterstudio.NL, 2021). The most popular options are still the Arken, Scharken and Woonschepen.

\section{SEA LEVEL AND FLOATING ASSETS}

Global sea levels are rising at an alarming rate. The Intergovernmental Panel on Climate Change (IPCC) estimate a rise of $90 \mathrm{~cm}$ by 2099 . The Antarctic ice sheetmelting rate has accelerated threefold over the last five years; meanwhile the Arctic sea ice volume reached a record low. In addition, for these reasons and others the exposure to natural hazards doubled in the last 40 years, affecting a high number of the worldwide population, meaning some areas of the world are at risk of disappearing entirely over the next few decades.

Cities have been tiptoeing into the water ever since we started building harbours; to tackle the urban pressures of population density and climate change, some countries are reclaiming land to build much-needed homes. Moreover, a cheap way to combat this threat, rather than build on land, is to use houseboats.

As floating houses are able to adapt to floods or tides, they could become the next big thing. And their potential to make use of old infrastructure and to conserve and generate energy currently outweighs any environmental concerns.

\section{CONCLUSIONS}

The evolution of the Canals in the UK and especially London have showed that they can be a measurement tool of societal needs. The increasing number of house boats in London is a challenge for local authorities, that will have to accommodate those new boating requirements in an already crowded landscape. In 2018 the CRT published London Mooring Strategy, which outlines a range of ongoing initiatives to sustainably increase the mooring spaces and facilities. As the current boaters are starting to suffer from the price-out scenario, how to manage the waterways may require a further social approach to avoid only the leisure companies to be present. Which may affect the bohemian look of the canals and their residential use.

Certainly, living conditions have improved from the one's boaters endured during the $18^{\text {th }}$ and $19^{\text {th }}$ Centuries, but due to the short supply of residential moorings, they are at risk of deteriorating. The need to improve the facilities and infrastructure is imperative to protect the rights of all waterways users and the rest of the public.
Around the globe, people have been living on the water for a long time, from Seattle to Macau. The idea of floating architecture is no longer a vision of the future, it is a reality.

\section{REFERENCES}

1. BAGWELL, P. (1988). The Transport Revolution 1770-1985. Routledge.

2. BROWNING, B. (1879). The Canal Boats Act, 1877. The British Medical Journal. December. p. 1046

3. CANAL \& RIVER TRUST (2019). Press release July 2019.

4. CANAL \& RIVER TRUST (2020). Annual Report \& Accounts 2019/20.

5. CANAL \& RIVER TRUST (2020). Waterway dimensions. October 2020 update.

6. GOURVISH, T. R. (1980). Railways and the British Economy 1830-1914. Macmillan Press Ltd.

7. MITCHELL, B. CHAMBERS, D. and CRAFTS, N. (2009), How good was the profitability of British Railways, 1870-1912? University of Warwick.

8. OFFICE for NATIONAL STATISTICS, LAND REGISTRY. (2020). Housing affordability in England and Wales: 2019.

9. RHODES, C., HOUGH, D. and BUTCHER, L. (2014) Research Paper 14/61. House of Commons Library. p. 21.

10. WATERSTUDIO NL. Arkup - Avant-garde life on water. Arkup 75. Retrieved January 3, 2021, from https://arkup.com/

11. WRIGLEY, E. A. (1962). The Supply of Raw Materials in the Industrial Revolution. The Economic History Review, 15, 1-16. 